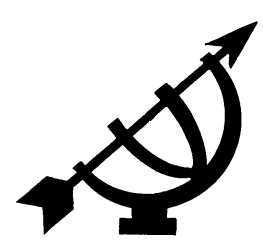

\title{
Project management: a new service delivery paradigm
}

\author{
Gerrit van der Waldt \\ Department Public Management \& Governance \\ School of Social \& Government Studies \\ Potchefstroom Campus \\ North-West University \\ POTCHEFSTROOM \\ E-mail: Gerrit.vanderwaldt@nwu.ac.za
}

\begin{abstract}
Project management: a new service delivery paradigm
\end{abstract}

In line with international trends in governance, the South African Government's initial focus on the development of policy frameworks, structures and systems in order to give effect to the values and principles of the Constitution, shifted to the most critical issue, namely service delivery. The Government became increasingly aware that a significant expansion in the scope and quality of service provision was not possible with traditional delivery settings and approaches. There is growing evidence that there is a need for a significant departure from conventional approaches and that a leap into a new service delivery paradigm is necessary. Increasingly this new paradigm highlights the need to further develop the government's project management skills and applications with a view to achieving improved delivery capability.

In this article the focus will be placed on the changing service delivery paradigm - from an "old" traditional model through the transition to a "new" paradigm. This paradigm is shaped by international and national trends and events in government. The contribution and advantages of project management applications for effective governance are highlighted and the article concludes with an explanation of project management organisational arrangements necessary to support the new paradigm. 


\section{Opsomming}

\section{Projekbestuur: 'n nuwe diensleweringsparadigma}

In ooreenstemming met internasionale tendense in regerings, het die Suid-Afrikaanse Regering se aanvanklike fokus op die ontwikkeling van 'n beleidsraamwerk, strukture en stelsels om uiting te gee aan die waardes en beginsels van die Grondwet, verskuif na die mees kritieke kwessie, naamlik dienslewering. Die Regering het toenemend tot die besef gekom dat 'n dramatiese uitbreiding in die omvang en kwaliteit van dienslewering nie moontlik was met die tradisionele diensleweringsmetodes en -benaderings nie. Daar is groeiende bewyse dat daar 'n behoefte is om 'n beduidende sprong vanaf meer konvensionele benaderings na 'n nuwe diensleweringsparadigma te maak. Hierdie nuwe paradigma dui toenemend daarop dat die regering se projekbestuursvaardighede en -toepassings verbeter moet word ten einde diensleweringsvermoëns te verhoog.

In hierdie artikel word die fokus geplaas op die veranderende diensleweringsparadigma - vanaf ' $n$ "ou" tradisionele model deur 'n transformasieproses na 'n "nuwe" paradigma. Hierdie paradigma word beïnvloed deur internasionale en nasionale tendense en gebeure in die regering. Die bydrae en voordele verbonde aan die toepassing van projekbestuur vir effektiewe regering word beklemtoon en die artikel sluit af met 'n verklaring van organisatoriese reëlings wat nodig is om die nuwe paradigma te rugsteun.

\section{Introduction}

Since 1994, South Africa's first democratically elected Government focused primarily on the development of policy frameworks, structures and systems to give effect to the values and principles of the Constitution of the Republic of South Africa (Act 108 of 1996) and to lay the foundation for democratic governance. Considerable progress has been made in this regard as can be witnessed by a myriad of policy papers in nearly every sector of the government. But, as the new policy frameworks were operationalised, attention increasingly shifted to the most critical issue, namely service delivery. In line with international trends, the Government became increasingly aware that a significant expansion in the scope and quality of service provision was not possible with traditional delivery approaches. There is growing evidence that there is a need for a significant departure from conventional approaches and that a massive leap into a new service delivery paradigm is necessary. Increasingly this new paradigm highlights the need to further 
develop the Government's project management skills and applications with a view to achieving improved delivery capability.

In this article the focus will be placed on the changing service delivery paradigm - from an "old" traditional model through the transition to a "new" paradigm. This paradigm is shaped by international and national trends and events in the government. The "old" paradigm will first be explored after which emphasis will be placed on the Government's transformation processes towards a new paradigm. The contribution and advantages of project management applications for effective governance will then come under the searchlight. The article concludes with an explanation of project management organisational arrangements necessary to support the new paradigm.

\section{Service delivery: pressure on the "old paradigm"}

\subsection{The concept paradigm}

The concept paradigm commonly refers to a pattern, model, thought-framework, or "the prevailing view of things" (see Clarke \& Clegg, 2000; Dogan, 2001). Kuhn (1996:12) adopted the word to refer to a set of practices that define a scientific discipline during a particular period of time. A prevailing paradigm dictates the kind of questions that are asked and probed for answers in relation to a specific issue. It also determines how answers to such questions are interpreted (Hassard, 1993:71). A paradigm thus could create a groupthink or mindset challenge, which could lead to so-called thinking "inside the box" (box = paradigm). When theorists encounter anomalies which cannot be explained by the universally accepted paradigm a shift in thinking usually occurs. According to Kuhn (1996:13) a paradigm is thrown into a state of crisis, during which time new ideas are tried and tested. Eventually a new paradigm is formed, which gains its own new followers. An intellectual "battle" takes place between the followers of the new paradigm and the old paradigm (Hassard, 1993). With this context as background, it is the contention of this article that the existing paradigm of service delivery (globally and nationally) is in a state of crisis and that a new delivery paradigm is emerging - a paradigm in which project management as delivery mechanism would feature prominently. 


\subsection{Service delivery: pressures for change}

In a significant number of countries pressure for public sector reform stems largely from economic conditions. Faced with the spectre of recession, fiscal crises and rising levels of inflation, many governments had put their public services under intense scrutiny. In part, the pressures were fiscal, but they were also motivated by public demand for better services. Access to improved public services is a right enshrined in the United Nations Declaration of Human Rights, in particular Article 21(2), which states: "Everyone has the right to equal access to public service." Whenever they are affected, cuts to public expenditure, encompassing basic services such as water, electricity, health and education, and impact directly on human beings. Globally, there is thus pressure on the government to deliver public services that make a material difference to people's lives.

Also in South Africa there are major pressures for a renewed focus on the issue of "service delivery". These pressures are directly the result of the far-reaching process of socio-political and economic transformation taking place in South Africa as well as, more indirectly, major rethinking about the nature and role of public sector institutions in many developing and developed countries. Central to this rethinking has been a major re-definition and realignment of the traditional ways in which service provision is managed in the public service. As a result, the public service in South Africa is undergoing radical change. In the White Paper on the Transformation of the Public Service (SA, 1995) and the White Paper on Public Service Delivery (SA, 1997) the Government set itself ambitious goals for transforming public services, and public institutions are being reformed, rationalised and restructured to meet these challenges. The new policy framework seriously questions the old paradigm and redefine the role of the Public Service - laying considerable emphasis on a service with the following goals:

- to be more responsive and relevant to the needs of citizens;

- to be more efficient and effective in the use of public resources;

- to be more representative of the diversity and needs of all, especially, the most disadvantaged sectors of society;

- to improve access to services, make them more responsive to the needs of citizens;

- to be more flexible and more efficient in the use of allocated funding; 
- to remove the command/control approach of management and accompanying excess regulation;

- to have the ability to adjust policies and processes when societal problems are detected;

- to better utilise technology in the delivery of services; and

- to remove public/private sector competition and promote partnerships.

With the policy framework in place, the critical issue increasingly became the question of service delivery itself. In assessing the current service paradigm, one should keep in mind that the challenges confronting the public service in South Africa does not by any means lie only with institutional and managerial issues. The challenges of service delivery are indeed much more complex and are deep-rooted in the historical, socio-economic, geo-political and other contexts of South Africa.

\subsection{Perspectives on public service transformation}

To move from an old to a new paradigm requires a transformation process. Transformation consists of rapid and radical change in all the facets of an organisation. These changes may be so significant that they result in a new organisational culture (Drucker, 1995:71). Transformation creates new relationships between an organisation and its environment. These new relationships may in turn alter both the organisation and its environment (see Senge, 1990; Waterman, 1991). An important consequence of public service transformation in South Africa has been the changing nature of state-society interaction and exchange.

Transformation, furthermore is also a process invention, which requires new visions, new ways of thinking and new management vocabulary. It requires a deliberate process of intervention, learning and development (Gerloff, 1985). Such interventions and development resulted in reforms such as privatisation and "contracting out" of public services, the introduction of private sector-type management strategies and objectives into the public sector, the allowance for private involvement in the delivery of public services, and the perception of the recipients of such services as "customers" have contributed to this change in the relationship between the public and private sectors. This change has not only changed state-society relations; it has also questioned existing criteria for public sector efficiency, urged that private providers of public services become 
legitimate actors on the "public market" and introduced new models for public sector management. This thinking provided the stimulus for the emerging New Public Management (NPM) paradigm.

\subsubsection{Challenges and constraints associated with the old paradigm}

This paradigm of finding radical new ways of service delivery, however, confronts political and managerial mental models, existing organisational values and cultures, behaviour habits established over years, and bureaucratic inertia. To overcome these and other challenges and constraints in service delivery, it will be necessary to address a number of important constraints, such as the following:

- Structural constraints. Government departments are still in the process of restructuring and are therefore not yet adequately geared to provide or facilitate the quality and quantity of service delivery needed. In addition, insufficient strategic planning capacity results in uncoordinated activities, causing unnecessary wastage of scarce resources and sometimes contradictory policies that defeat national objectives.

- Functional constraints. In some departments the vision, policies and strategic plans to steer appropriate service delivery are not fully in place. They are therefore not in a position as yet to devise optimal implementation strategies. Operational units within departments often lack the necessary delegated authority and responsibility in areas such as finance, procurement and personnel functions to provide prompt and effective service delivery.

- Process constraints. Many of the processes and procedures, through which services are provided, are still largely based on ruled-based bureaucratic norms and practices. The result is that these processes continue in many ways to serve the bureaucratic needs of the Public Service rather than the needs of citizens.

- Resource constraints. Most departments suffer from serious shortages of resources (such as office space, equipment, computers, software, and so on), which inhibits their service delivery capacity. In the area of financial management, adherence to the stipulations of the Public Finance Management Act 1 of 1999 and a general lack of appropriately trained staff lead to ineffective financial accountability and control, thus aggravating the waste of scarce resources. Service delivery is also constrained by the lack of staff in general, and the lack of skilled and representative staff in particular (especially in the professional and technical areas). 


\subsection{Stability and transformation: the paradigmatic paradox}

A paradox is likely to be a key element of a new paradigm for service delivery. In a paradox "everything is its opposite" (Hock, 1994: 78). A central paradox in government transformation is that political and managerial leaders strive to maintain stability or equilibrium, but that transformation requires instability since energy for creative change comes from being off-balance - or, as Peters (1992:34) states: "you're only in control when things are out of control". A state of near-chaos provides special impetus for transformation (see Quinn \& Cameron, 1988:44).

\section{Towards a new service delivery paradigm: transitional arrangements}

It is well documented that South Africa, as a developmental state, faces major challenges such as the elimination of poverty, the minimisation of crime, economic growth and many more. Government has a central role to play in dealing with these challenges. The ability of the state and its machinery to act is largely defined by the capability and commitment of the Public Service to translate national policy into programmes and projects of action. The role of Government's executive authorities and structures to implement policies demand the integration of all variables into a coherent implementation framework for the successful translation of policies into service delivery.

Some political observers have argued that policy-making in South Africa has sometimes been inward-focused. They contend that the objective has been "to serve political heads" and that this focus at times veered public managers towards a focus on policy advice rather than on implementation - an outward focus. The New Public Management (NPM) paradigm and the publication of books, articles and reports with themes such as "reinventing government" (Osborne \& Gaebler, 1993), "government re-engineering", "government renewal strategies", "modernising and revitalising", "organisational transformation", and so forth, propagate an outward or customer focus. This outward focus of the bureaucracy has as its main drivers issues such as increased efficiency by improving the input-output ratio (the percentage of operational and capital budgets spent on bureaucracy maintenance versus the percentage spent on service delivery); increased accountability, transparency and democratisation of Government operations; improve resource management; and an improved relationships between community and Government. 


\subsection{Service delivery and the "reinventing"-movement}

Around the globe, government renewal involves rethinking the government's "business" and trying to improve service delivery to achieve government objectives. Government has been criticised for being overly bureaucratic, slow to respond, inefficient and unimaginative.

There is a general trend internationally for the state to play a minimalist, managerialist role. This means removing itself from direct service delivery i.e. provision of services, cutting the size of the state/public sector, and cutting the state budget, which means cutting spending in the public sector and on welfare areas. This approach sees the state as fundamentally inefficient when it comes to service delivery, and state spending as a disincentive to private sector investment. Government is redefined into a core administrative structure which focuses on strategy and policy making, and which regulates service delivery rather than providing services directly; government enters into a series of contracts, partnerships and network arrangements with a range of service providers.

The famous work of Osborne and Geabler, Reinventing government (1993), provided a strong impetus for this debate. The Global Forum on Reinventing Government was further established to share governance experiences across the globe. In determining the appropriate role for government a frequent analogy is that government should focus on "steering" not "rowing". Management scholars suggest that government should concentrate only on policy and regulatory functions and rely on the "outside" (private and "third" sector) for the delivery of programs. Theorists, however, urges caution in adopting such a simplistic analogy. Compelling reasons exist for public sector delivery of many programs. The language of "reinventing government" draws heavily on the vocabulary of business. Government programmes are seen as serving clients and stakeholders, not citizens. Government managers are asked to define their business. Providing a vision of where the South African Public Service should be and how the state can facilitate that movement is not on the agenda.

\subsection{Alternative service delivery and South Africa}

In line with global trends, the South African Government's intention is also to shift to smaller and more flexible programme delivery arrangements and to decentralise authority so that government operations become more client-oriented and innovative in delivering 
public services. In order to facilitate these delivery arrangements, Government is moving to create more and more alternative service delivery (ASD) mechanisms. A brief analysis of the official guideline documents associated with these delivery mechanisms clearly indicate that projects are seen as vehicles for implementation. In the case of Public-Private-Partnerships (PPP) as alternative delivery mechanism, for example, multi-disciplinary project teams comprising members of all institutions involved in ventures, are the main drivers for implementation.

ASD can be defined as the provision of public services through arrangements other than the traditional departmental structure. A wide variety of approaches are being used both within and outside the public sector. The establishment of an alternative service delivery approach is usually linked to the desire for better, more affordable service, in which case its design should reflect these goals and facilitate their attainment.

In the ASD approach the risk for development, ownership, operation and upgrading are shared by those public and private sector agencies best suited to carry that risk. The Department of Public Service and Administration, for example, established a Centre for Public Service Innovation (CPSI) with a view to incrementally and continuously improve service delivery mechanisms through innovation and creativity.

Other mechanisms to facilitate alternative service delivery in South Africa include the following:

- E-Governance: This is the use of information and communication technology (ICT) to deliver certain services electronically. According to this approach to service delivery, government utilises internet technology to improve quality (better services), efficiency (cost effectiveness), and effectiveness (economic development). In 2000 Government established the State Information Technology Agency (SITA) to create an uniform ICT-platform for governance.

- Privatisation, commercialisation and corporatisation: Privatisation generally means injecting sound, proven, private-sector techniques into public sector activities. Commercialisation (also referred to as "service shedding") occurs where Government stops providing a service and lets the private sector assume the function. In corporatisation government institutions are reorganised along business lines. Typically they are required to pay 
taxes, raise capital on the market (with no government backing explicit or implicit), and operate according to commercial principles. Government corporations and parastatals focus on maximising profits and achieving a favourable return on investment. They are freed from government procurement, personnel and budget systems.

- Outsourcing: Often outsourcing give public institutions greater quality through the access it provides to superior technologies, quality controls and processes. It furthermore is sometimes the only option due to lack of internal staff, financial and other capacities. Some institutions may choose to "off-load" the restraints on their capacities and ability to deliver the right services at the right time.

- Public-private partnerships: Delivering public services through public-private partnerships (PPPs) is relatively new in South Africa. Support for service delivery through PPPs varies across government institutions. Different modes of service delivery is part of a larger (including international), socio-political and economic debate concerning the role of government in public service delivery. These benefits can result in better or more services for the same price, or in savings that can fund other services or more investment elsewhere (SA, 2000:6).

This concludes the brief overview of the changing service delivery paradigm, both nationally and internationally. Next, the application of Project Management in service delivery will be explored.

\section{Project Management: theoretical perspectives}

Young (1996) and Maylor (1996:3) define a project as

... a collection of linked activities, carried out in an organised manner with a clearly defined start and finish point, to achieve some specific results that satisfy the needs of an organisation as derived from the current business plan.

In turn, Kerzner (2003) defines projects as any series of activities and tasks that have a specific objective to be completed within specification; have defined start and end dates; have funding limits; consume human and other resources and are multi-functional. A project may therefore be viewed as the entire process required to produce a new product, service, process, system or other results within an established budget. It is thus the management of anything that has a beginning, a clear and final end and whose output is 
subject to time, budget, quality and resource constraints (see Willson-Murray, 1997; Van der Waldt \& Knipe, 1998:58; Venter, 2005:81).

Project management was established as a popular discipline in the late 1960s and 1970s, through the creation and activity of the United States and European project management societies and through the widespread adoption in business, government and the military of the matrix form of organisation (Burke, 2006:7). The main driving force in the 1980s and 1990s was mainly in the area of computer tools and software applications (Cleland \& Ireland, 2002).

Project management is internationally recognised as a profession and in South Africa, a professional body, Project Management Institute South Africa (PMISA), was established to ensure quality in project management practices. One of the key contributions and products of PMISA is the Project Management Body of Knowledge (PMBOK) guide which highlights nine knowledge areas of project management, namely quality management, human resource management, cost management, communication management, procurement management, scope management, integration management, risk management, and time management.

Over time a wide variety of models emerged to study the processes associated with projects. A "model" is used to identify, monitor, measure and benchmark a progression of steps or methodology in a project cycle. A model could lead to an organisation's ability to implement strategies and programmes through effective, efficient, and consistent steps (Jugdev \& Thomas, 2002:5). Models are gaining interest as organisations and theorists strive to make sense of why some projects succeed and others not (Lewis, 2002:2).

\section{The value of a project management paradigm in service delivery}

Any analysis of the significance of project management in the South African Government should have as starting point the identification of key governance issues. In other words, if there is a problem, to what extent could project management be part of the solution? The drivers behind the emphasis on project management should thus be uncovered. 


\subsection{Drivers for project management application: towards a new paradigm}

Arguably the main driver behind the application of project management in government is to improve state institutions' ability to deliver efficient, effective and high quality services. The Constitution of the Republic of South Africa Act 108 of 1996, Chapter 10, Section 195(1)(b \& c), for example lay the foundation for drivers by stipulating that South Africa's Public Service must promote efficient, economic and effective use of resources and that it must be development-oriented. The Public Finance Management Act 1 of 1999 (Part 2, Section 38(b)), a further example, stipulates that accounting officers are responsible for the "... effective, efficient, economical and transparent use of the resources of the department". As statutory drivers these stipulations place significant emphasis on the optimal utilisation of departmental resources by focusing on outcomes. It further focus attention on getting things done on time (efficient), within budget (economical) and according to certain quality standards (effective). There are also increased accountability requirements on public sector institutions, leading to a greater focus on effectiveness and efficiency in the way functions are performed. Project management can support the achievement of institutional goals, as well as give greater assurance to stakeholders that resources are effectively managed (Srivannaboon \& Milosevic, 2006: 495). Applying a formalised project management framework, or methodology to projects can help with clarification of, and agreement to goals, identifying resources needed, ensuring accountability for results and performance, and fostering a focus on final benefits to be achieved.

Recent reports (2003) by the United Kingdom Government, titled "Better policy making" and "Identifying good practice in the use of programme and project management in policy-making: transforming public services; a civil service that delivers", identified a number of good practice examples in the development and implementation of policy. These reports clearly state that programme and project management (PPM) are proven approaches to effective service delivery. They continue by arguing that the

... advantages of using PPM techniques are that they offer a discipline to control resources and to manage risk more effectively. They encourage formal recognition of responsibilities and a focus on what a project is to deliver. 
Project management should be the focal point for policy-makers in that they should think through the end-to-end process to translate a particular policy into delivery plans and delivery plans into desired outcomes. This so-called "end-to-end" policy-making is important to consider implementation and delivery from the start. By incorporating the issues and perspectives from operational systems and structures, policy-implementation is simplified. The involvement of project managers, for example, throughout the process can strengthen the "deliverability" of the outcomes and commitment to the policy objectives.

A further value of good project management is that there are standardised processes in place to deal with all contingencies. Using sound project management techniques and processes will give a higher likelihood that service delivery projects will be completed on time, within budget and to an acceptable level of quality. It also provides a framework, process, guidelines and techniques to greatly increase the odds of being successful (Cleland \& Ireland, 2002:4). The UK Government, for example, utilises the Prince 2 methodology and rigidly reviews major projects at key points. Use of the methodology is estimated to save 500 million pounds per year in improved value (Winter et al., 2006:641). In this context the value of good project management centres around the fact that departments could develop standardised processes and procedures (methodologies and methods) to deal with all output and outcome-driven initiatives in state departments.

Below, a synopsis of the main value of project management in service delivery is made.

- Quality services. In line with the Batho Pele-principles and the processes associated with comprehensive performance management systems of departments, effective project management includes quality management processes which will assist the department to understand the customer's quality specifications (service standards), and to establish quality control and quality assurance techniques.

- Relationships and networking. Problems on a project can be avoided with effective communication. Much of the conflict that does arise on a project is not the result of a specific problem, but because of misunderstandings. A project methodology focuses on the development of a network of role-players and stakeholders, which results in fewer misunderstanding. Many projects experience problems because there is a gap between what the 
beneficiaries or client expects and what the project team delivers. Using a systematic process results in better project planning, which gives the team an opportunity to make sure they are in agreement on the major deliverables produced by the project.

- Financial management. Better cost estimation, formal budgeting and better tracking of actual costs result in better financial predictability and control.

- Proactive termination of "bad" projects. "Bad" projects are those where the cost-benefit justification no longer makes sense. If the project is late and over-budget, it may be no longer realistic. Project methodology facilitates a pro-active look to anticipate these situations earlier for re-scoping or termination decisions. Project management methodology provides guidance to make it easier to collect metrics (measures). Metrics provide the right information to determine how effective and efficient the project is running and the level of the quality of its deliverables. Metrics also provide information necessary to validate whether the project was successful or not.

- Efficiency and effectiveness. Once the processes and standardised procedures are created, they can be used on similar projects in the future. This results in reduced project start-up time, a shorter learning curve for project team members and time savings from not having to reinvent processes and templates from scratch on each project. Some teams spend too much time and energy dealing with problems because they do not know how to resolve the problems to begin with. Having a proactive issues management process helps ensure that problems are resolved as quickly as possible.

- Resource utilisation. Having better project management processes will result in departments being able to manage the scope of a project more effectively, which will result in cost and other resource savings.

- Resolving risks. Effective project management include processes to identify and manage risks. Sound risk management processes will result in potential problems being identified and managed before the problems actually occur.

- Conducive work environment. Team members that work on projects with serious challenges tend to be demoralised and unproductive. With effective methodology the project team will take more ownership of the project, the morale will be better, and the 
project team will behave with a greater sense of professionalism and self-confidence.

Next, the new delivery paradigm will be explored and steps to support this paradigm will be highlighted.

\section{The new paradigm: managing by projects}

Managing by projects as a management approach has increasingly become popular due to the increased interest in process redesign. Organisations begin to view all changes to their organisational processes as "project oriented" (Pollack, 2007:268). Organisations committed to the managing by projects philosophy categorises all activity as "projects" of either "change" or "operational" categories. The managing by projects concept affects all aspects of an organisation, beginning with the development of corporate strategy and continuing through the strategic and operational planning cycles (In't Veld, 1999; Bresnen, 2007:366).

An organisation using the above approach treats all work as a project, beginning with the evaluation of potential projects against the corporate strategy. Operational plans for all functional groups are prepared with a project orientation and reviewed as such. The output of the complete process is a set of project and resource plans aligned with the strategy.

Managing by projects involves the entire organisation, and the systems which support it must also span across multiple levels and departments. The best and most useful systems have the flexibility to adapt and evolve along with the organisation. Organisations who have taken this approach find that there are still barriers to succeeding with their product introduction process. These barriers revolve around making teams work from both a structural and cultural point of view, such as the following:

- Communications between the project management organisation and the functional departments due to the size and complexity of the projects and their simultaneous activities.

- Allocating and managing valuable and scarce resources across the multiple project organisations, ensuring the high priority, strategy-critical projects are getting the correct priority attention.

- Repeating early successes achieved by high management focus and attention on early implementations focused on key projects. 
- Spreading, repeating and sustaining these successes to all projects.

Managing by projects is seen as the best approach in challenging these issues and has a track record of success in the organisations which have implemented it (Crawford, Pollack \& England, 2006: 177). Organisations committed to this approach, distinguish between the operational business plan, which addresses the requirements of the current organisation, core business processes, and cost structure, and the strategic business plan, which addresses the issue of the "vision" for moving to a new organisation, and revised organisational processes and cost structure.

\subsection{Supporting the new paradigm: the need for structural, systemic and cultural adjustments in government}

As indicated earlier transformation from an "old" to "new" delivery paradigm is an incremental process. Public institutions cannot expect officials to change the way they have done things for years, over night. Proper management of the transition of people through the process of change is critical to the success of a new system. There are typically three aspects to the transition of people through transformation, namely the discontinuation of the old way of doing business, migration, and starting the new way of doing business (see Dey, 1999:148). Thus, for project management to get entrenched as a new service delivery paradigm in government certain adjustments are needed to migrate from the old paradigm to a new way of delivering services. This new business will require structural, systemic and cultural adjustments.

Project management is about organisational and cultural change ("soft" issues) as well as delivery ("hard" issues). As far as the hard issues, or structures are concerned, it is advisable not to juxtapose project structures on traditional functional or hierarchical department structures. Ideally, the structures of a department should be revised to fully accommodate portfolios, programmes and projects.

\subsubsection{Structural change}

In a highly dynamic environment, traditional bureaucratic structures are usually not adaptable or flexible enough to rapidly adjust to changing conditions. The opposite is true for project-based organisational structures. With faster response to needs and demands, better utilisation of resources, and improved project control and performance, project-based organisations have the flexibility re- 
quired to maximise their efforts. Change to the existing hierarchical, bureaucratic structures may thus be necessary to support the utilisation of projects. These structural changes should be supported by the introduction of new functional and authorative procedures and practices (see Pinchot \& Pinchot, 1994).

Project-based management generally stems from one or several key organisational drivers. These drivers determine whether a government department could successfully operationalise its constitutional and democratic mandates. These drivers may vary from department to department, but the challenge of adapting existing organisational structures to a programme and project-based structure is unique for each situation. These changes are often met with inherent resistance from those reluctant or unwilling to change (Van der Waldt, 2001).

Internationally, one of the most recent organisational structures instituted to support the utilisation of projects is the Project Support Office (PSO). Initially created to support the migration of organisations towards a more project-oriented management style, including the establishment of processes and procedures, it has become in recent years the favoured framework for the management of projects. Departments which utilise PSOs experience the freedom for functional managers to concentrate on the operational aspects of the department, while the PSO takes care of the crossfunctional activities taking place with a number of teams brought together from various directorates on a temporary basis to deliver a product and/or service (Van der Waldt, 2001). Typically PSO should be a central pool of skilled and experienced staff members to provide project support to all projects running in the department (Aubry, Hobbs \& Thuillier, 2007:332). The overall objectives of a PSO are to support managers in project administration and to ensure correct and efficient use of standardised project methodology across all projects.

\section{Department/programme/project-interfaces}

Typical government projects are multi-dimensional which requires multi-disciplinary cross-functional teams from various clusters to manage. In line with the spirit of co-operative governance, government institutions on all spheres of government should co-operate to give effect to project deliverables. Typical challenges in this regard include clear roles, responsibilities, and lines of communication and reporting; financial transfers; the physical transfer of officials from one department to another department; and cultural barriers. 
To ensure the optimal utilisation of scarce departmental resources, projects should be aligned with programmes and existing organisational structures and arrangements (Martinsuo \& Lehtonen, 2007: 58). It is therefore necessary to establish and improve interfaces between the programme, individual projects and organisational arrangements. These interfaces generally fall into one of three categories:

- Organisational interfaces: formal and informal reporting relationships among different organisational units or directorates.

- Technical interfaces: formal and informal reporting relationships among different technical disciplines and functional areas. Technical interfaces occur both within project phases and between project phases.

- Interpersonal interfaces: formal and informal relationships among different individuals working on programmes and projects.

These interfaces often occur simultaneously and provision should be made to incrementally improve and maintain them. The use of steering committees or other mechanisms of governance may significantly assist to facilitate these interfaces. A steering committee could, for example, ensure that a particular project obtain resources from various functional directorates (organisational interfaces), get assistance from IT (technical interface), and bring all role-players (i.e. heads of directorates) frequently to the table to establish work practices and to foster relationships (interpersonal interfaces).

\subsubsection{Cultural adjustments}

Typically over time government departments develop unique and describable organisational cultures. These cultures are reflected in their shared vision, value system, norms, beliefs, and expectations; in their policies and procedures; in their view of authority relationships; and in numerous other factors. These cultures could have a significant impact on the success of projects. A department with very strong hierarchical structures and highly authoritarian styles, may inhibit the flexibility that project managers require to adapt quickly to changing circumstances (Schein, 1993). In such a rigid, bureaucratic work environment it would be problematic to obtain approval to secure additional funding and other resources. Culture change does not come only as a result of a change in the system. It comes as a result of consistent (incremental) change in the way people feel about that system. Human beings must see that there is more benefit associated with the change than in not changing. 
Developing a culture that sees individual projects as elements of the business plan can be a difficult problem. This is especially the case if there is reluctance within the ranks of senior management to admit uncertainty about what project management really means.

\section{Bureaucratic inertia}

Max Weber defined the character of "bureaucracy" - a form of organisation which is characterised by its formal hierarchical structure, compliance with rigid rules and control, stability (inherent resistance to change), and mechanistic nature (Blau \& Meyer, 1971). These characteristics are deeply rooted in public institutions. The bureaucrat's employment contract (of which civil service codes would be a current example) offers great job security in exchange for loyalty to official policies and procedures; it expects that the employee will leave personal prejudices and agendas at home and perform the duties of the job impartially, objectively, without prejudice or passion, but just according to "the book" (see Kanter, 1983). The classic model of bureaucracy wants its workers to "act like robots" (Blau \& Meyer, 1971:64); or, what Hock (1994) refers to as "mindcrafting". This is a central issue for the application of project management: the struggle between control or rigid forces and creativity and flexibility forces necessary to successfully manage projects. It is therefore necessary for the management of changes to the organisational culture, functional processes, job design, staff skills, and policies and procedures.

\subsubsection{Systemic adjustments}

To implement project management practices involves the methodologies, procedures and standards that determine the project organisation with the roles and responsibilities of the project team, as well as the procedures and decision making processes. Key objectives of this component include:

- Clarify project and functional roles and responsibilities.

- Provide visibility of resources (including answers to questions such as: What skills are required? Do we have the capacity to take on a new project?)

- Ensure the decision-makers have the information and tools to measure the impact of the decisions that are made. 
- Establish a consistent vocabulary and management reporting process that provides an appropriate level of visibility, and improves decision-making.

By following these and other critical success factors, project managers and senior management can ensure that projects are integrated with existing organisational systems and that there is alignment between projects and departmental strategic objectives.

\section{Conclusion}

Globally there are clear indications that public institutions are going to be managed differently. Developments such as the reinventing government movement and new public management signal the emergence of a new service delivery paradigm. In this new paradigm public institutions will increasingly utilise alternative service delivery approaches and mechanisms to provide services. These approaches and mechanisms will require integrated, functional systems and procedures that are dynamic, flexible, and accountable.

The utilisation of project management in government results in a new implementation "tool-kit" for public service managers and service providers. From this article it should, however, be clear that structural, systemic, cultural and procedural adjustments need to be made to inculcate a new paradigm and to incorporate processes and procedures to support project applications. The resulting managing by projects paradigm will add significant benefits to both service providers and service beneficiaries.

\section{List of references}

AUBRY, M., HOBBS, B. \& THUILLIER, D. 2007. A new framework for understanding organisational project management through the PMO. International journal of project management, 25(4):328-336.

BLAU, P. \& MEYER, W. 1971. Bureaucracy in modern society. New York: Random House.

BRESNEN, M. 2007. Deconstructing partnering in project-based organisation: seven pillars, seven paradoxes and seven deadly sins. International journal of project management, 25(4):365-374.

BURKE, R. 2006. Project management: planning and control techniques. 5th ed. London: Technical Books.

CLARKE, T. \& CLEGG, S., eds. 2000. Changing paradigms. London: HarperCollins.

CLELAND, D.I. \& IRELAND, L.R. 2002. Project management. New York: Library of Congress Cataloguing in Publishing Data. 
CRAWFORD, L., POLLACK, J. \& ENGLAND, D. 2006. Uncovering the trends in project management: journal emphases over the last 10 years. International journal of project management, 24(2):175-184.

DEY, P.K. 1999. Process re-engineering for effective implementation of projects. International journal of project management, 17(4):147-159.

DOGAN, M. 2001. Paradigms in the social sciences. International encyclopedia of the social and behavioral sciences, 16:121-133.

DRUCKER, P. 1995. Managing in a time of great change. New York: Dutton.

GERLOFF, E.A. 1985. Organisational theory and design. New York: McGraw Hill.

HASSARD, J. 1993. Sociology and organisation theory: positivism, paradigm and postmodernity. London: Cambridge University Press.

HOCK, D. 1994. Institutions in the age of mindcrafting: paper presented at the Bionomics Annual Conference, San Francisco.

IN'T VELD, C. 1999. Managing by project into the 21st century: paper presented at the Project Management Institute South Africa (PMISA), Regional African Project Management Conference, Midrand, South Africa.

JUGDEV, K. \& THOMAS, J. 2002. Project management maturity models: the silver bullets of competitive advantage? Project management journal, 33(4):4-14.

KANTER, R.M. 1983. The changemasters: innovations for productivity in the American corporation. New York: Simon \& Schuster.

KERZNER, H. 2003. Project management: a system approach to planning, scheduling and controlling. New Jersey: Wiley.

KUHN, T.S. 1996. The structure of scientific revolutions. 3rd ed. Chicago: University of Chicago Press.

LEWIS, J.P. 2002. Fundamentals of project management. New York: Amacon.

MARTINSUO, M. \& LEHTONEN, P. 2007. Role of single-project management in achieving portfolio management efficiency. International journal of project management, 25(4):56-65.

MAYLOR, H. 1996. Project management. London: Pitman.

OSBORNE, D. \& GAEBLER, T. 1993. Reinventing government: how the entrepreneurial spirit is transforming the public sector. New York: Plume.

PETERS, T. 1992. Liberation management. New York: Knopf.

PINCHOT, G. \& PINCHOT, E. 1994. The end of bureaucracy and the rise of the intelligent organization. San Francisco: Berret-Koehler.

POLLACK, J. 2007. The changing paradigms of project management. International journal of project management, 25(3):266-274.

QUINN, R. \& CAMERON, K., eds. 1988. Paradox and transformation: toward a theory of change in organizations and management. Cambridge: Ballinger.

SA

see SOUTH AFRICA

SCHEIN, E.H. 1993. Organizational culture and leadership. 2nd ed. San Francisco: Bass.

SENGE, P. 1990. The fifth discipline. New York: Doubleday.

SOUTH AFRICA. 1995. White Paper on Transformation in the Public Service. Government notice 376 of 1995. Pretoria: Government Printer.

SOUTH AFRICA. 1996. The Constitution of the Republic of South Africa, Act 108 of 1996. Pretoria: Government Printer.

SOUTH AFRICA. 1997. White Paper on Transforming Public Service Delivery (Batho Pele). Pretoria: Government Printer. 
SOUTH AFRICA. Department of Finance: 2000. A strategic framework for delivering public services through public-private partnerships. www.finance.gov.za Date of access: April 2000.

SRIVANNABOON, S. \& MILOSEVIC, D.Z. 2006. A two-way influence between business strategy and project management. International journal of project management, 24(6): 493-505.

VAN DER WALDT, G. 2001. Establishing a management by projects approach for service delivery. Journal for public administration and management, 36(4):72-84.

VAN DER WALDT, G. \& KNIPE, A. 1998. Project management for strategic change and upliftment. Johannesburg: Thomson.

VENTER, F. 2005. Project management in Ghana: expectations, realities and barriers to use. The journal for transdisciplinary research in Southern Africa, 1(1):77-96.

WATERMAN, R.H. 1991. Adhocracy: the power to change. New York: Norton.

WILLSON-MURRAY, R. 1997. Managing projects: a new approach. Brisbane: Wiley.

WINTER, M., SMITH, C., MORRIS, P. \& CICMIL, S. 2006. Directions for future research in project management: the main findings of a UK governmentfunded research network. International journal of project management, 24(2):638-649.

YOUNG, T.L. 1996. The handbook of project management: a practical guide to effective policies and procedures. London: Kogan Page.

\section{Key concepts:}

alternative service delivery

project management

service delivery

transformation

Kernbegrippe:

alternatiewe dienslewering

dienslewering

projekbestuur

transformasie 